\title{
In-house Placement of Freshman Students for the EAP Program in a Hospitality-Specialized Institution
}

\author{
Hsiao-I Hou (Corresponding author) \\ Chief of Language Education Section \& Assistant Professor of Department of Applied \\ English, National Kaohsiung University of Hospitality and Tourism \\ 1 Son-He Rd., Kaohsiung 812, Taiwan, ROC \\ Tel: 886-7-8060505 E-mail: houx0020@gmail.com
}

Received: November 23, 2014 Accepted: December 7, 2014 Published: December 10, 2014

doi:10.5296/ijele.v3i1.6765 URL: http://dx.doi.org/10.5296/ijele.v3i1.6765

\begin{abstract}
In the language testing field, in-house placement tests are not often mentioned in research. The purpose of this study is to discuss the development of a new in-house placement test for an English for academic purposes (EAP) program at a hospitality-specialized university in Taiwan. The context of the program and the test development process are described. The testing purposes and formats are also presented. Based on quantitative analyses, the test results are interpreted. Practical teaching applications for this particular program and future research suggestions are provided.
\end{abstract}

Keywords: Language testing; placement test; Common European Framework of Reference (CEFR) 


\section{Introduction}

When discussing issues in English as a Second Language (ESL) or English as a Foreign Language (EFL) testing, the purpose of assessment is an important topic. Assessments can be used for screening and identification, placement, reclassification or exit, monitoring learners' progress, and program evaluation (Bachman, 1990; Bachman \& Palmer, 1996). Because of their different needs and purposes, language teachers and program administrators may need different types of tests. Administrators need language testing results for placement, exemption or exit from a program. Language teachers need different testing results to provide evidence of progress, diagnoses, feedback to students and program evaluation (Feak \& Salehzadeh, 2001).

In the language testing field, two main issues need to be considered: reliability and validity. Reliability focuses on issues related to whether the assessment can produce consistent results. It also relates to the instrument's accuracy and how the assessment is scored (Fulcher, 1997). Validity describes whether the instrument can assess what is intended to assess. In other words, the results or scores of a valid test should be able to provide specific information about the learner's learning outcomes (Fulcher, 1997). Cohen (1994) mentions that if the instrument does not measure what it is supposed to assess, there is no value to the testing scores or results.

To satisfy the aforementioned issues while conducting research about language testing or placement tests, the attention has mainly been focused on large-scale language assessment, such as the Test of English as a Foreign Language (TOEFL) or the International English Language Testing System (IELTS) (Feak \& Salehzadeh, 2001). However, these tests are not designed for placement purposes. Some language program directors will use other language proficiency tests, such as the Combined English Language Skills Assessment (CELSA) or the Comprehensive English Language Test (CELT). The problem with this type of tests is that the test results do not match the level of learners' language skills with individual course objectives or outcomes. As a result, students will be misplaced. In another situation, the language program directors will buy placement test from publishers or design the test based on a particular textbook. As Brown (1989) explains, these approaches cause two problems. First, because the students' abilities vary widely, the effectiveness of the given placement test can be questionable. Second, while ESL/EFL students are from different countries or have various cultural or language backgrounds, the test questions are unrelated to the needs of particular language programs.

To avoid aforementioned problems, an in-house placement test can be the ideal solution when there is sufficient expert input (Brown, 1989, 2005; Feak \& Salehzadeh, 2001). Current research in language testing seldom focuses on issues related to in-house placement test development. The purpose of this study is to report the development of an in-house placement test for an EAP program in a hospitality-specialized institution in Taiwan. In addition, based on the test results, practical recommendations for this program are made. It is believed that this study can bring valuable information to language program directors that have unique program designs or have particular populations of learners. 


\section{The EAP Program at the Hospitality-Specialized Institution in Taiwan}

In this study, the hospitality-specialized institution is a leading public vocational university in Taiwan. There are 13 undergraduate and 3 graduate departments and programs affiliated with the following colleges: the College of Hospitality Management, the College of Tourism, the College of Culinary Arts and the International College. With its unique curriculum design and outstanding reputation, this public university is the most popular higher education institution among vocational high school students in Taiwan (Hou, 2013). In order to satisfy the graduation requirement, the bachelor's degree students need to obtain at least 132 credits and finish a one-year paid internship during their third year in a position related to their professions. The internship is placed through the school's Internship Office, and both overseas and domestic opportunities are available (Hou, 2013).

For the four-year bachelor degree program, students have to take 4 credits in English listening and speaking and 4 credits in English reading and writing in their first year. These courses are part of the General Education (GE) required courses. The listening and speaking classes are taught in smaller classes with fewer than 30 students, but the reading and writing classes are offered in a regular class size of approximately 52 students. In their second year, students have to take an advanced two-credit English listening and speaking class as a GE requirement, along with another two-credit English for specific purposes (ESP) class that is offered by their departments and has content related to their majors.

Preparing students with confidence and increasing their motivation are the objectives of the first-year English training course. Based on students' proficiency levels, survival English or English for academic purposes (EAP) are the main themes. To provide English professional terminology for students' internships, the second-year English listening and speaking course content is integrated with hospitality-related themes, including restaurants, hotels, culinary arts, travel, and events.

\subsection{The In-house English Placement Test}

As Lynch and Davison (1994) and Fulcher (1999) recommend, it is important to emphasize the link between course objectives and assessment contents. A company that specializes in developing online mock proficiency tests designed the English placement test, and this institution's placement test had been used over five years. It mainly focused on testing for general purposes. There were 25 questions related to vocabulary and reading comprehension. The other 25 questions tested for listening comprehension, which included listening for picture descriptions, short conversations and speeches. The test took 50 minutes to complete, and the total score was out of 100 . However, the test results did not reflect and correspond with students' proficiency levels. In addition, it did not provide administrators or teachers with sufficient information to interpret the meaning of the scores. In previous years, students and teachers also complained about misplacement. Some students were misplaced in courses that were either too difficult or too easy; therefore, they asked to switch levels or classes.

In Fall 2012, the Ministry of Education conducted an accreditation procedure for this institution and revealed that students were not satisfied with the current GE English program. Later, a curriculum revision committee was formed, including deans of academic affairs and 
colleges and directors of departments and centers, to review issues and problems in current curriculum design. Finally, the committee agreed to develop a new placement test for freshmen enrolled in Fall 2014. The committee hoped that recommendations and suggestions for the revision of GE English programs could be made based on the new placement test results.

\subsection{The New In-house Placement Test and the Testing Format}

Based on the committee's decisions, there was a need to revise the GE English program's existing English placement test and curriculum design. Several meetings and interviews were conducted to obtain opinions and information from administrators, textbook publishers, students and instructors. In addition, previous years' testing results and students' entrance exam data and backgrounds were analyzed. By collecting this comprehensive information, the testing purposes and format were finalized.

\subsubsection{The Testing Purposes}

The new placement test sought to (a) implement a system in which students of differing English proficiency levels were placed in the EAP listening-speaking or reading-writing courses that corresponded to their respective levels; (b) obtain a preliminary understanding of the English proficiency of freshman students enrolled for the academic year and then use that information as a teaching reference for instructors; (c) acquire a preliminary understanding of the differences in four English skills of students enrolled in various colleges or in various departments within each college; (d) specifically observe and track students who performed poorly on the English test and adopt effective supplementary teaching approaches to improve their English proficiency; and (e) further develop the link between GE English courses and each department's ESP courses, thus enabling students to graduate with improved English skills in EAP and ESP domains.

\subsubsection{Testing Approaches and Test Questions}

Based on previous years' data analyses, learners' proficiency levels should be in the range of Common European Framework of Reference (CEFR) Levels A2 to B1 (Jones \& Saville, 2009). The new placement testing results should be able to identify the students' proficiency levels by comparing them with the CEFR. After investigating several tests in the market, the new version of the Test of English for International Communication (TOEIC) was adopted as the format. The Educational Testing Service (ETS) developed the TOEIC, which measures the ability of nonnative speakers of English to listen and read in English in the global workplace. The testing questions and content simulate real-life situations that are relevant to the global workplace (ETS, 2014). In addition, the test results can be transferred to the CEFR (ETS, 2007). After multiple revisions, a shorter version of the mock TOEIC (with 50 multiple-choice questions) was developed as the new in-house placement test. The questions were written and offered by a commercial testing company. A pilot test was conducted and given to two staff members, three language instructors and 16 second- and third-year students who had formal TOEIC scores. Students' test scores on both the in-house placement test and formal TOEIC were compared and analyzed. Several adjustments were made based on the 
feedback and results from the pilot.

The test consisted of two parts, namely listening and reading:

(1) Listening

This part included 25 questions and required approximately 13 minutes to complete. The content of the test items included narrations, questions, short conversations, and short talks. With a time meter on the screen and using headphones, the participants listened to the questions and answer choices before they answered based on what they heard.

Section 1: Three questions about photographic descriptions (select one of four choice items)

Section 2: Seven question-response questions (select one of three choice items)

Section 3: Divide into groups of three, nine questions about three short conversations (select one of four choice items)

Section 4: Divided into two groups of three, six questions about three short talks (select one of four choice items)

(2) Reading

This part contained 25 questions and required approximately 18 minutes to complete. The contents included commonly used vocabulary and grammar in daily life and business, grammatical error recognition, and essay reading. The participants read the essays at their own pace with a time limit and answered questions based on the contents.

Section 5: Ten questions relating to incomplete sentences (select one of four choice items)

Section 6: Three text completion questions based on a short passage (select one of three choice items)

Section 7: Twelve reading comprehension questions based on three short and long essays (select one of four choice items)

The scores from the new placement test were converted into TOEIC scores, using the TOEIC Score Conversion Chart (WIE, 2013). The results indicated that the scores for listening were higher than those for reading when the numbers of correct answers were identical. The test items were mock items; therefore, the scores that were converted based on the chart were approximate values that could serve as references.

\section{Placement Testing Results}

In this study, a total of 788 freshman students enrolled in 4-year bachelor degree programs and participated in the placement test. There were 722 Taiwanese students (91.6\%) and 66 international students (8.4\%). Among the international students, 30 were from Malaysia (3.8\%), accounting for the majority, followed by 14 from Indonesia (1.8\%), 6 from Macau $(0.8 \%), 3$ from Hong Kong, 3 from Vietnam, 2 from Japan, and 1 from each of the following countries: South Korea, Australia, New Zealand, the United States, Nicaragua, Singapore, Burma, and Brazil. 
The 788 students represented 12 departments (students from the English department did not have to take the placement test), and Table 1 shows the numbers of students from each department. Students from the College of Hospitality Management accounted for the majority, and students from the International College were the smallest in number. By department, the highest proportion of students was from the Department of Hotel Management, followed by students from the Department of Food and Beverage (F\&B) Management and the Department of Leisure and Recreation. In contrast, the Department of International Tourism and the Department of International Culinary Arts had the smallest proportion of students.

Table 1. Distribution of freshman student participants

\begin{tabular}{cccc}
\hline College & Number & Department & Number \\
\hline \multirow{2}{*}{ Tourism } & 199 & Travel Management & $50(6.3 \%)$ \\
& $(25.3 \%)$ & Aviation and Transportation & $54(6.9 \%)$ \\
& & Leisure and Recreation & $95(12.1 \%)$ \\
\hline \multirow{2}{*}{ Hospitality } & 323 & Hotel Management & $159(20.2 \%)$ \\
Management & $(41 \%)$ & F\&B Management & $112(14.2 \%)$ \\
& & Event Management & $52(6.6 \%)$ \\
\hline \multirow{2}{*}{ Culinary Arts } & 165 & Western Culinary Arts & $50(6.3 \%)$ \\
& $(20.9 \%)$ & Baking Technology and & $59(7.5 \%)$ \\
& & Management & \\
International & 101 & Chinese Culinary Arts & $56(7.1 \%)$ \\
& $(12.8 \%)$ & Applied Japanese & $47(6.0 \%)$ \\
& & International Tourism & $29(3.7 \%)$ \\
& & International Culinary Arts & $25(3.2 \%)$ \\
\hline
\end{tabular}

\subsection{Test Score Analysis}

The 788 students received an average score of 258.82 for listening and 255.40 for reading, yielding an average total of 514.22 (CEFRB1). The highest score was 865 , attained by a student from Class 1B in the Department of Hotel Management; the lowest score was 5, attained by a student from Class 1B in the Department of F\&B Management. In addition, $19.3 \%$ of the students received scores lower than 350 (CEFR A2), and 50\% received scores lower than 530 (CEFR B1).

Among international students from non-English-speaking countries, students from Indonesia exhibited the highest average score (625.36), followed by students from Malaysia (508.83) and Hong Kong (483.3). Students from South Korea received the lowest average score (140), and the average scores for students from Macau and Burma were also relatively low (417.5 and 420 , respectively).

An analysis of the scores that students from various departments attained on the placement test (Table 2) indicated that students from the Department of International Tourism received the highest average total score (682.59), followed by students from the Department of 
International Culinary Arts (666.80), the Department of Aviation and Transportation (602.13), and the Department of Western Culinary Arts (522.80). In contrast, students from the Department of Chinese Culinary Arts received the lowest average total scores (339.29), followed by students from the Department of Applied Japanese (448.30), the Department of Baking Technology and Management (463.47), and the Department of Travel Management (471.60).

Table 2. Average total scores, average scores for reading and listening, and SD of students from various departments

\begin{tabular}{|c|c|c|c|c|c|c|c|}
\hline College & Department & $\begin{array}{l}\text { Avg. } \\
\text { Total } \\
\text { Score }\end{array}$ & SD & $\begin{array}{l}\text { Avg. } \\
\text { Listening } \\
\text { Score }\end{array}$ & SD & $\begin{array}{l}\text { Avg. } \\
\text { Reading } \\
\text { Score }\end{array}$ & SD \\
\hline \multirow[t]{3}{*}{ Tourism } & $\begin{array}{c}\text { Travel } \\
\text { Management }\end{array}$ & 471.60 & 168.58 & 235.20 & 101.66 & 236.40 & 87.31 \\
\hline & $\begin{array}{l}\text { Aviation and } \\
\text { Transportation }\end{array}$ & 602.13 & 147.70 & 297.41 & 91.91 & 304.72 & 68.32 \\
\hline & $\begin{array}{l}\text { Leisure and } \\
\text { Recreation }\end{array}$ & 528.42 & 158.55 & 262.58 & 93.57 & 265.84 & 84.93 \\
\hline \multirow[t]{3}{*}{$\begin{array}{l}\text { Hospitality } \\
\text { Management }\end{array}$} & $\begin{array}{c}\text { Hotel } \\
\text { Management }\end{array}$ & 534.59 & 158.87 & 266.29 & 96.82 & 268.30 & 82.27 \\
\hline & $\begin{array}{c}\text { F\&B } \\
\text { Management }\end{array}$ & 490.13 & 156.25 & 244.33 & 94.23 & 245.80 & 83.02 \\
\hline & $\begin{array}{c}\text { Event } \\
\text { Management }\end{array}$ & 528.75 & 176.58 & 263.46 & 107.71 & 265.29 & 86.68 \\
\hline \multirow[t]{3}{*}{ Culinary Arts } & $\begin{array}{c}\text { Western } \\
\text { Culinary Arts }\end{array}$ & 552.80 & 156.13 & 289.90 & 96.11 & 262.90 & 76.90 \\
\hline & $\begin{array}{c}\text { Baking } \\
\text { Technology } \\
\text { Management }\end{array}$ & 463.47 & 188.88 & 226.61 & 108.99 & 236.86 & 97.54 \\
\hline & $\begin{array}{c}\text { Chinese Culinary } \\
\text { Arts }\end{array}$ & 339.29 & 168.26 & 175.00 & 98.14 & 164.29 & 89.53 \\
\hline \multirow[t]{3}{*}{ International } & $\begin{array}{l}\text { Applied } \\
\text { Japanese }\end{array}$ & 448.30 & 162.42 & 234.79 & 99.45 & 213.51 & 90.57 \\
\hline & $\begin{array}{l}\text { International } \\
\text { Tourism }\end{array}$ & 682.59 & 119.61 & 358.62 & 72.20 & 323.97 & 56.95 \\
\hline & $\begin{array}{l}\text { International } \\
\text { Culinary Arts }\end{array}$ & 666.80 & 89.62 & 347.20 & 79.22 & 319.60 & 44.58 \\
\hline
\end{tabular}

An analysis of the average scores for listening indicated that students from the Department of International Tourism received the highest average score (358.62), followed by students from the Department of International Culinary Arts (347.20), the Department of Aviation and Transportation (297.40), and the Department of Western Culinary Arts (289.90). In contrast, students from the Department of Chinese Culinary Arts exhibited the lowest average score 
for listening (175.00), followed by students from the Department of Baking Technology and Management (226.61), the Department of Applied Japanese (234.79), and the Department of Travel Management (235.20). For the average reading scores, students from the Department of International Tourism received the highest average score (323.97), followed by students from the Department of International Culinary Arts (319.60), the Department of Aviation and Transportation (304.72), and the Department of Hotel Management (268.30). In contrast, students from the Department of Chinese Culinary Arts exhibited the lowest average score for reading (164.29), followed by students from the Department of Applied Japanese (213.51), the Department of Travel Management (236.40), and the Department of Baking Technology and Management (236.86).

\subsection{Analysis of students with scores in the top $20 \%$ and the bottom $20 \%$}

The descriptive statistics described in the previous sections indicated that students from various classes, departments, and colleges differed substantially in average total scores and average scores for listening and reading. Therefore, additional analyses were conducted for students with total scores in the top $20 \%$ and the bottom $20 \%$ of the 788 -student sample.

Table 3 shows that 157 students attained total scores that placed them in the top $20 \%$, with scores ranging from 675 to 865 (CEFR B2-C1). More than half of the students in this group were from the College of Hospitality Management; more than one-third were from the College of Tourism; and more than one-fifth were from the International College. The highest proportion of students was from the Department of Aviation and Transportation (13.4\%), followed by students from the Department of International Tourism (10.2\%), the Department of International Culinary Arts (9.6\%), and the Department of Western Culinary Arts (9.6\%). Dividing the number of students in the top $20 \%$ by the number of students in each of the classes indicated that the percentage of students that attained total scores that placed them in the top $20 \%$ accounted for more than $40 \%$ of the students in the Department of Aviation and Transportation; approximately $30 \%$ of the students in the Department of Western Culinary Arts; $60 \%$ of the students in the Department of International Culinary Arts; and 55\% of the students in the Department of International Tourism.

Table 3. Distribution of students with total scores in the top $20 \%$

\begin{tabular}{cccc}
\hline College & Number of students & Department & Number of students \\
\hline & & Travel Management & $2(1.3 \%)$ \\
& & Aviation and Transportation & $21(13.4 \%)$ \\
Tourism & $39(24.8 \%)$ & Leisure and Recreation 1A & \\
& & Leisure and Recreation 1B & $9(5.7 \%)$ \\
& & & $7(4.5 \%)$ \\
Hospitality & $58(36.9 \%)$ & Hotel Management 1A & $11(7.0 \%)$ \\
Management & & Hotel Management 1B & $10(6.4 \%)$ \\
\cline { 3 - 4 } & &
\end{tabular}




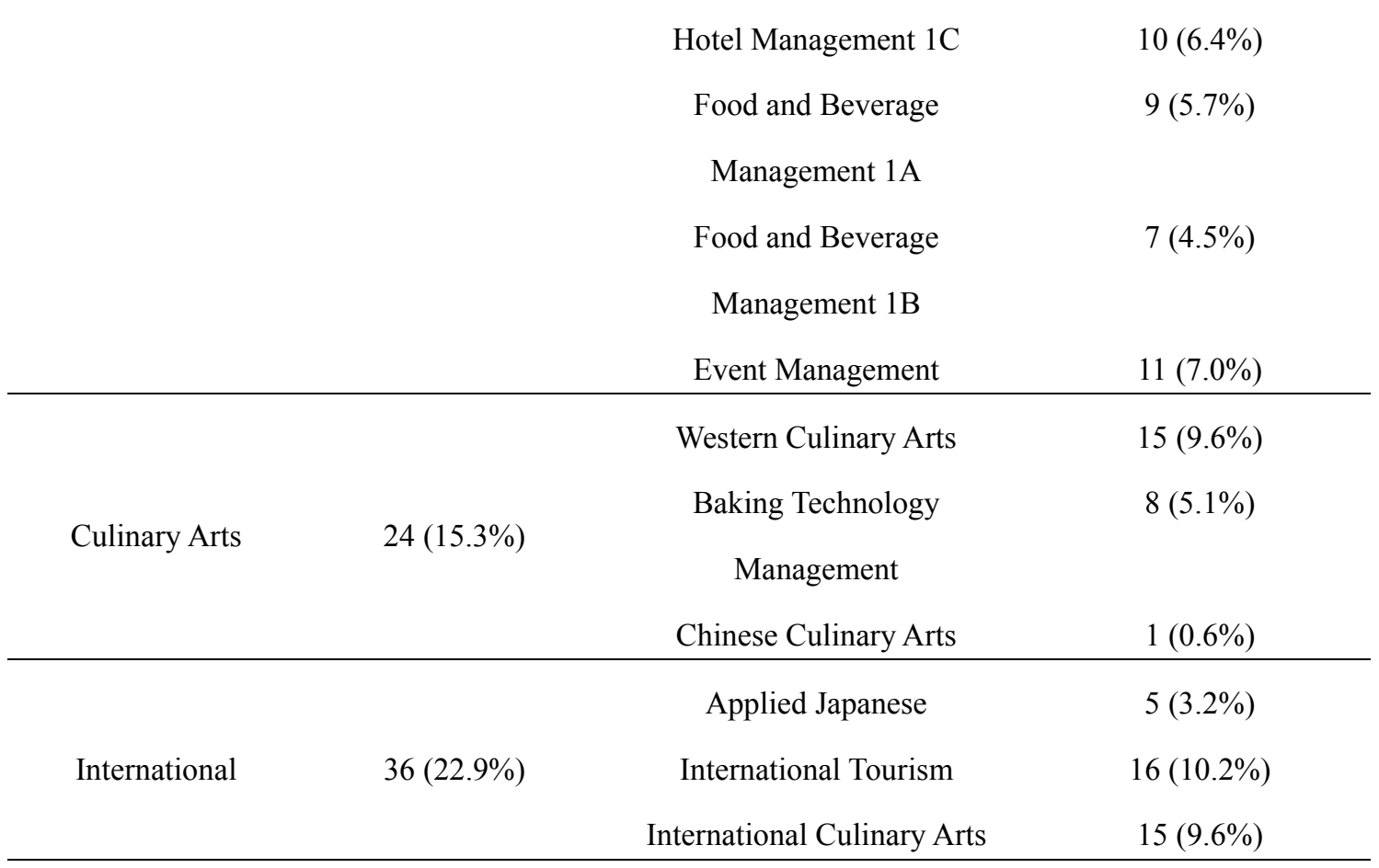

Table 4 shows that 152 students received total scores that placed them in the bottom $20 \%$, with scores ranging from 5 to 350 (CEFR A1-A2). More than one-third of these students were from the College of Hospitality and Tourism and the College of Culinary Arts; $17.8 \%$ were from the College of Tourism; and almost 10\% were from the Department of Applied Japanese in the International College. However, no students from the Department of International Tourism and the Department of International Culinary Arts were in this group. Students from the Department of Chinese Culinary Arts accounted for the highest percentage (19.1\%), followed by students from the Department of Baking Technology and Management (11.8\%) and the Department of Applied Japanese (9.9\%). Dividing the number of students in the bottom $20 \%$ by the number of students in each of the classes indicated that the percentage of students who had total scores that placed them in the bottom $20 \%$ accounted for more than $50 \%$ of the students in the Department of Chinese Culinary Arts; approximately $30 \%$ of the students in the Department of Baking Technology and Management; and almost one-third of the students in the Department of Applied Japanese.

Table 4. Distribution of students with total scores in the bottom $20 \%$

\begin{tabular}{cccc}
\hline College & Number of students & Department & Number of students \\
\hline & & Travel Management & $12(7.9 \%)$ \\
& & Aviation and Transportation & $3(2.0 \%)$ \\
Tourism & $27(17.8 \%)$ & Leisure and Recreation 1A & \\
& & Leisure and Recreation 1B & $6(3.9 \%)$ \\
\hline
\end{tabular}




\begin{tabular}{|c|c|c|c|}
\hline \multirow{6}{*}{$\begin{array}{l}\text { Hospitality } \\
\text { Management }\end{array}$} & \multirow{6}{*}{$55(36.2 \%)$} & Hotel Management 1A & $9(5.9 \%)$ \\
\hline & & Hotel Management 1B & $8(5.3 \%)$ \\
\hline & & Hotel Management 1C & $7(4.6 \%)$ \\
\hline & & F\&B Management 1A & $13(8.6 \%)$ \\
\hline & & F\&B Management 1B & $8(5.3 \%)$ \\
\hline & & Event Management & $10(6.6 \%)$ \\
\hline \multirow{4}{*}{$\begin{array}{c}\text { College of } \\
\text { Culinary Arts }\end{array}$} & \multirow{4}{*}{$55(36.2 \%)$} & Western Culinary Arts & $8(5.3 \%)$ \\
\hline & & Baking Technology and & $18(11.8 \%)$ \\
\hline & & Management & \\
\hline & & Chinese Culinary Arts & $29(19.1 \%)$ \\
\hline \multirow{3}{*}{ International } & \multirow{3}{*}{$15(9.9 \%)$} & Applied Japanese & $15(9.9 \%)$ \\
\hline & & International Tourism & $0(0 \%)$ \\
\hline & & International Culinary Arts & $0(0 \%)$ \\
\hline
\end{tabular}

Analyses regarding these two groups of students indicated that students in various classes differed significantly in terms of English proficiency. Approximately $40 \%-60 \%$ of the students in the Department of Aviation and Transportation, the Department of International Tourism, and the Department of International Culinary Arts ranked in the top 20\% of all freshman students. Courses in the Department of International Tourism and the Department of International Culinary Arts were taught in English; therefore, students' English proficiency was expected to improve considerably, rather than decline, in the English-only learning environment during their sophomore and senior years. However, whether students received opportunities to use English frequently during the internship during their third year was uncertain. Teachers in other departments should carefully review the English learning needs of students in the top 20\%. In addition to the 10 credits of GE English courses on listening, speaking, reading, and writing that are offered during the first year and the first semester of the second year, program directors should design professional courses and professional English courses that can satisfy the learning requirements of these students and encourage them to engage in overseas internships, through which the students can improve their English skills.

In contrast, more than $30 \%-50 \%$ of the students in the Department of Chinese Culinary Arts, 
the Department of Baking Technology and Management, and the Department of Applied Japanese were ranked in the bottom $20 \%$ due to their scores on the placement test. It is recommended that teachers follow the performance of these students over an extended period or determine the English learning processes of these students to identify their requirements and the difficulties that they encounter while learning English. Similarly, in addition to the 10 credits of GE English courses for listening, speaking, reading, and writing that are offered to freshmen and during the first semester of their second year, program directors should design supplementary English support and extra-curriculum activities for freshmen. Furthermore, professional English courses should be designed to help these students and enable them to achieve the English requirements for graduation.

\section{Conclusion}

The new in-house placement test conducted in this institution was the first one that simulated questions from the new TOEIC. Students' scores were converted using the TOEIC Score Conversion Chart and can be mapped with the CEFR level. As a result, the data in this study were much more meaningful to the administrators, program directors, teachers and students and are convenient for use in the analysis and comparison of students' scores to determine their proficiency levels. The score can recognize the learner's strengths and weakness and then further identify the skills that he or she needs to improve. In addition, the scores can interpret whether the learners can perform certain tasks successfully in specific contexts (Powers, Kim, \& Weng, 2008). Furthermore, the results of the report can serve as a reference for identifying differences in the English proficiency of freshman students from various classes, departments, and colleges. It provides useful data to teachers and administrators, and they will then know how and what to improve in the curriculum to satisfy students' needs. After the Fall 2014 semester began, none of the students complained about misplacement or asked to switch levels. It is believed that the test measures what should be distinguished and that the test results are useful and meaningful.

Based on the statistics presented in the previous sections, the following key points were summarized and offered recommendations regarding relevant support that can be provided:

1. The faculty members and administrators should clearly understand the placement testing purposes and testing formats. They should know what skills the learners are testing for and must have a thorough understanding of testing results interpretation. It is important that program design, course content, materials, and teaching strategies are linked with test results.

2. The results of the analyses could help the faculty and language instructors to estimate the English proficiency level of the students who enrolled in this academic year. Based on the testing results, it is necessary to tailor course objectives for different levels of GE English classes. The English proficiency of all students can thus be enhanced comprehensively. In this regard, the report can serve as a reference for administrators, chairs, and instructors in relevant departments to determine students' English proficiency. After understanding students' existing English proficiency levels, instructors offering GE English courses and professional courses can then provide appropriate English input for students. 
3. It is recommended that all the information (e.g., students' placement test scores, English course grades, and records of the English learning activities that students have participated in since freshman year) should be integrated into their learning portfolio. Each student establishes individual English learning portfolios and examines whether they spent sufficient time on learning English during their 4 years of college and whether they have fully maximized the resources offered by the university to improve their English proficiency.

4. The GE Language Center should conduct long-term tracking and provide extra support for students who rank in the bottom $20 \%$ on the freshman English test. In addition to identifying their needs and the difficulties they encounter while learning English, remediation courses should be offered to this group of students. Furthermore, the online English-learning resources available on the library website should be employed to encourage students to engage in self-learning. By increasing the number of hours spent on learning English weekly, particularly on improving English reading skills and expanding English vocabulary, students can enhance English proficiency and reach CEFR Levels A2-B1.

5. For the students with scores that place them in the top $20 \%$ on the placement test, their needs in English learning will be very different from the rest of the students. In addition to 10 credits of advanced GE English courses, they can participate in special extracurricular English-learning activities that are organized by the Language Center. Furthermore, their affiliated departments should organize extra tasks or advanced English classes to enhance their English learning. Thus, these students can achieve English proficiency higher than CEFR Level C2.

6. The structures of general English courses and professional English courses should be comprehensively planned and connected to ensure that students can improve English proficiency and that student learning is not fragmented. Students who have earned 10 credits from GE English courses are expected to achieve CEFR Levels B1-B2 or above. Therefore, in addition to improving students' ability to use professional English terminology, the professional English courses offered in each department should be targeted to enable students to achieve CEFR Levels B2-C1.

Developing appropriate placement procedures in educational settings is important because it creates long-term impacts on students' language and academic progress. The process for developing the new in-house English placement test is challenging; however, the test results provide valuable information to improve course quality. Students were placed in the appropriate levels; teachers obtained score information as a reference for understanding students' weaknesses and strengths. In addition, as Powers, Kim, and Weng (2008) mentioned, "language learners often have more complete knowledge of their linguistic successes and failures than do third-party assessors" (p. 11). Students can also use the score results as a self-assessment tool to measure their progress in English learning.

For future studies, it is necessary to obtain both quantitative and qualitative information on students' reactions to this test on a large scale. Extra data (e.g., students' previous education 
backgrounds, English learning experience, GPAs, or overseas experience) can be compiled to conduct further studies to predict students' success in English courses or as alternative assessment methods to measure learners' English proficiency. In addition, because student populations and program design are different from school to school, each institution is encouraged to develop or identify the most suitable placement mechanisms accordingly. Thus, future research can focus on the development of placement tests for unique language programs.

\section{Acknowledgement}

This research was supported by the Teaching Excellence Project subsidized by the Ministry of Education in Taiwan. The author expresses her thanks to her colleague, Ms. Tzu-pei Kuo, who provided insight and expertise that greatly assisted the research.

\section{References}

Bachman, L. F. (1990). Fundamental considerations in language testing. Oxford: OUP.

Bachman, 1. F., \& Palmer, A. S. (1996). Language testing in practice. Oxford, OUP.

Brown, J. D. (1989). Improving ESL placement tests using two perspectives. TESOL Quarterly, 23(1), 65-83. http://dx.doi.org/10.2307/3587508

Brown, J. D. (2005). Testing in language programs: A comprehensive guide to English language assessment. NY: McGraw-Hill.

Cohen, A. (1994). Assessing language ability in the classroom. Boston: Heinle \& Heinle Publishers.

ETS. (2014). The TOEIC Tests - the global standard for assessing English proficiency for $\begin{array}{lll}\text { Business. } & \text { Retrieved 2014/09/10 from }\end{array}$ https://www.ets.org/toeic/succeed?WT.ac=toeichome_succeed_121127.

ETS. (2007). Mapping the TOEIC and TOEIC Bridge Tests on the Common European Framework of Reference for Languages. Retrieved 2014/09/12 from https://www.ets.org/s/toeic/pdf/toeic_cef_mapping_flyer.pdf

Feak, C., \& Salehzadeh, J. (2001). Challenges and issues in developing an EAP video listening placement assessment: a view from one program. ESP Journal, 20, 477-493.

Fulcher, G. (1997). An English language placement test: Issues in reliability and validity. Language Testing, 14(2), 113-138. http://dx.doi.org/10.1177/026553229701400201

Fulcher, G. (1999). Assessment in English for academic purposes: putting content validity in its place. Applied Linguistics, 20 (2), 221-236. http://dx.doi.org/10.1093/applin/20.2.221

Hou, H. (2013). A needs analysis of culinary arts majors' ESP learning in Taiwan's context. Asia ESP Journal, 9(3),5-34.

Jones, N., \& Saville, N. (2009). European language policy: assessment, learning and the CEFR. Annual Review of Applied Linguistics, 29, 51-63. 
http://dx.doi.org/10.1017/S0267190509090059 2015, Vol. 3, No. 1

Lynch, D., \& Davidson, F. (1994). Criterion-referenced language test development: linking curricula, teachers, and tests. TESOL Quarterly, 28 (4), 727-743. http://dx.doi.org/10.2307/3587557

Powers, D., Kim, H. J., \& Weng, V. (2008). The redesigned TOPEIC test: Relations to test-taker perceptions of proficiency in English. Retrieved 2014/09/12 from http://www.ets.org/Media/Tests/Test_of_English_for_International_Communication/TOEIC_ Can_Do.pdf

WIE. (2013). TOEIC scores and conversion table. Retrieved 2014/10/10 from http://wie.ac.nz/toeicconversion.htm

\section{Copyright Disclaimer}

Copyright for this article is retained by the author(s), with first publication rights granted to the journal.

This is an open-access article distributed under the terms and conditions of the Creative Commons Attribution license (http://creativecommons.org/licenses/by/3.0/). 